\title{
SISTEM INFORMASI PERENCANAAN PEMANFAATAN DAN PENGENDALIAN RUANG KOTA B
}

\author{
Rita Komalasari, S.Si.,M.Kom \\ Prodi Manajemen Informatika \\ Politeknik LP3I Bandung \\ Email: ritakomalasari123456@gmail.com
}

\begin{abstract}
Abstrak: Penyelenggaraan Sistem Elektronik di lingkungan Instansi Pemerintah Pusat dan Daerah, selanjutnya disebut e-government adalah pemanfaatan Teknologi Informasi untuk meningkatkan efisiensi, efektivitas, transparansi,dan akuntabilitas penyelenggaraan pemerintahan. Untuk melaksanakan amanat urusan penataan ruang tersebut, saat ini diperlukan sistem kerja yang sudah menerapkan platform EGovernment, mengingat perkembangan teknologi informasi yang pesat serta kecepatan kebutuhan informasi khususnya informasi penataan ruang yang semakin tinggi dari masyarakat, menuntut pemerintah harus cepat dalam melayani masyarakat dan pengambilan keputusan. Dengan demikian, Pemerintah Kota Bogor, membutuhkan sistem informasi yang dapat mengatasi kendala-kendala tersebut guna peningkatan kinerja pemerintah daerah khususnya dalam penyelenggaraan penataan ruang. Sistem informasi yang dimaksud adalah Informasi Perencanaan Pemanfaatan dan Pengendalian Ruang dalam bentuk perangkat lunak (aplikasi) baik yang dapat mengolah data secara tabular maupun spasial (Sistem Informasi Geografis).
\end{abstract}

Kata Kunci: e-government, GIS

\section{Pendahuluan}

Tantangan besar yang dihadapi Kota Bogor dalam lima tahun mendatang adalah bagaimana perkembangan teknologi informasi yang sedemikian pesatnya dapat dioptimalisasikan untuk mendukung pengelolaan kota. Dalam waktu-waktu mendatang, akan menjadi hal yang jauh tertinggal dan inefisien ketika pengelolaan kota masih dijalankan dengan cara-cara yang konvensional atau cara-cara yang selama ini dipraktekkan selama sekian lama.Perkembangan teknologi telah membawa berbagai kemudahan dalam hidup kita, dan seyogyanya teknologi itu juga dimanfaatkan dalam pengelolaan kota. Dalam konteks antar kota di Indonesia, Kota Bogor sudah sangat selayaknya mengimplementasikan sepenuhnya e-government.

Dengan demikian, Penyelenggaraan Sistem Elektronik di lingkungan Instansi Pemerintah Pusat dan Daerah, selanjutnya disebut e-government adalah pemanfaatan Teknologi Informasi untuk meningkatkan efisiensi, efektivitas, transparansi,dan akuntabilitas penyelenggaraan pemerintahan, dengan tujuan:

a. Meningkatkan mutu layanan publik melalui pemanfaatan teknologi IT dalam proses penyelenggaraan pemerintahan

b. Terbentuknya kepemerintahan yang bersih, transparan, dan mampu menjawab tuntutan perubahan secara efektif

c. Perbaikan organisasi, sistem manajemen, dan proses kerja kepemerintahan 
Salah satu urusan penyelenggaraan pemerintahan adalah urusan penataan ruang. Urusan ini berpijak pada UU No. 26 Tahun 2007 tentang Penataan Ruang, yang dijabarkan dalam PP No. 15 Tahun 2010 tentang Penyelenggaraan Penataan Ruang, bahwa :

a. Penyelenggaraan meliputi Pengaturan, Pembinaan, Pelaksanaan, Pengawasan.

b. Pelaksanaan Penataan Ruang meliputi perencanaan tata ruang, pemanfaatan ruang, dan pengendalian pemanfaatan ruang

c. Pengendalian pemanfaatan ruang meliputi Peraturan zonasi, perizinan, insentif dan disinsentif, dan sanksi

Badan perencanaan pembangunan daerah mempunyai tugas melaksanakan penyusunan dan pelaksanaan kebijakan daerah di bidang perencanaan pembangunan daerah

a. Badan perencanaan pembangunan daerah dalam melaksanakan tugas menyelenggarakan fungsi:perumusan kebijakan teknis perencanaan;

b. pengoordinasian penyusunan perencanaan pembangunan;

c. pembinaan dan pelaksanaan tugas di bidang perencanaan pembangunan daerah; dan

d. pelaksanaan tugas lain yang diberikan oleh walikota sesuai dengan tugas dan fungsinya.

\subsection{Maksud Dan Tujuan}

a. Maksud: Dapat dioperasikannya Sistem Informasi Perencanaan, Pemanfaatan dan Pengendalian Ruang

b. Tujuan:

1) Pengembangan konten fasilitas pelayanan informasi peruntukan ruang

2) Pengembangan konten dokumentasi perizinan dan pengawasan

3) Pengembangan aplikasi berbasis android

4) Pengembangan web tata ruang

5) Terpeliharanya sistem

6) Meningkatkan kemampuan operator sistem dari OPD terkait

\section{2 Target/ Sasaran}

Sasaran yang ingin dicapai dengan adanya aplikasi sistem informasi ini adalah dioperasikannya sistem informasi perencanaan, pemanfaatan dan pengendalian ruang

\section{Tinjauan Pustaka}

\subsection{Luas dan Batas Wilayah Administrasi}

Luas wilayah Kota Bogor sebesar 11.850 hektar yang terdiri dari enam kecamatan dan 68 kelurahan. Keenam kecamatan tersebut yaitu Kecamatan Bogor Selatan, Kecamatan Bogor Timur, Kecamatan Bogor Utara, Kecamatan Bogor Tengah, Kecamatan Bogor Barat dan Kecamatan Tanah Sareal.

Kecamatan Bogor Barat mempunyai luas wilayah terbesar yaitu 3.285 hektar dan terdiri dari 16 kelurahan sedangkan Kecamatan Bogor Tengah mempunyai luas wilayah terkecil yaitu 813 hektar dan terdiri dari 11 kelurahan. Untuk luas wilayah menurut kecamatan tersaji pada Tabel 1.

Secara administratif Kota Bogor dikelilingi oleh Wilayah Kabupaten Bogor dengan batas wilayah sebagai berikut (1) Sebelah Utara berbatasan dengan Kecamatan Kemang, 
Bojong Gede, dan Kecamatan Sukaraja Kabupaten Bogor. (2) Sebelah Timur berbatasan dengan Kecamatan Sukaraja dan Kecamatan Ciawi, Kabupaten Bogor. (3) Sebelah Barat berbatasan dengan Kecamatan Darmaga dan Kecamatan Ciomas, Kabupaten Bogor. (4) Sebelah Selatan berbatasan dengan Kecamatan Cijeruk dan Kecamatan Caringin, Kabupaten Bogor.

Tabel 1 Luas Wilayah Menurut Kecamatan di Kota Bogor

\begin{tabular}{|c|l|c|}
\hline NO & KECAMATAN & LUAS WILAYAH (HA) \\
\hline 1 & BOGOR SELATAN & 3.081 \\
\hline 2 & BOGOR TIMUR & 1.015 \\
\hline 3 & BOGOR UTARA & 1.772 \\
\hline 4 & BOGOR TENGAH & 813 \\
\hline 5 & BOGOR BARAT & 3.285 \\
\hline 6 & TANAH SAREAL & 1.884 \\
\hline & JUMLAH & 11.850 \\
\hline
\end{tabular}

\subsection{Tinjauan Tentang Sistem Informasi Perencanaan, Pemanfaatan dan Pengendalian Ruang}

\section{Perencanaan Pemanfaatan dan Pengendalian Ruang}

Menurut Peraturan Pemerintah Nomor 15 Tahun 2010 tentang Penyelenggaraan Penataan Ruang, ruang didefinisikan sebagai wadah yang meliputi ruang darat, ruang laut, dan ruang udara, termasuk ruang di dalam bumi sebagai satu kesatuan wilayah, tempat manusia dan makhluk lain hidup, melakukan kegiatan, dan memelihara kelangsungan hidupnya. Sedangkan Penataan ruang adalah suatu sistem proses perencanaan tata ruang, pemanfaatan ruang, dan pengendalian pemanfaatan ruang.

a. Perencanaan tata ruang adalah suatu proses untuk menentukan struktur ruang dan pola ruang yang meliputi penyusunan dan penetapan rencana tata ruang.

b. Pemanfaatan ruang adalah upaya untuk mewujudkan struktur ruang dan pola ruang sesuai dengan rencana tata ruang melalui penyusunan dan pelaksanaan program beserta pembiayaannya.

c. Pengendalian pemanfaatan ruang adalah upaya untuk mewujudkan tertib tata ruang. Ruang lingkup Sistem Informasi Perencanaan, Pemanfaatan dan Pengendalian Ruang

Ruang lingkup dan batasan Pembuatan Sistem Informasi Perencanaan, Pemanfaatan dan Pengendalian Ruang adalah sebagai berikut:

a. Database yang terhubung dengan SMART

b. Informasi peruntukan ruang :

1) Tersedianya fasilitas delineasi lokasi pada peta

2) Tersedianya fasilitas peta informasi peruntukan ruang, untuk dapat dicetak

c. Aplikasi android :

1) Aplikasi dapat digunakan oleh masyarakat untuk mengetahui zonasi RTRW

2) Aplikasi dapat digunakan oleh pemerintah untuk melakukan survey lokasi baik perizinan maupun pengawasan, khususnya penetapan posisi dan dokumentasi

d. Dokumentasi perizinan dan pengawasan :

Tersedianya fasilitas dokumentasi dokumen pendukung perizinan dan pengawasan baik berupa pdf maupun foto

e. Website, dapat menampilkan informasi :

1) Berita 
2) OPD

3) Produk Hukum

4) Perencanaan

5) Pemanfaatan

6) Pengendalian

7) Pelaporan

\section{Metode Pengembangan GIS}

Sistem Informasi Geografi (SIG)atau yang lebih dikenal dengan Geographic Information System (GIS) merupakan sistem yang dirancang untuk bekerja dengan data yang tereferensi secara spasial atau koordinat-koordinat geografi. GIS memiliki kemampuan untuk melakukan pengolahan data dan melakukan operasi-operasi tertentu dengan menampilkan dan menganalisa data. Pengembangan aplikasi GIS mengarah kepada aplikasi berbasis web yang dikenal dengan web GIS. Hal ini disebabkan karena pengembangan aplikasi di lingkungan jaringan telah menunjukan potensi yang besar dalam kaitannya dengan geo informasi. Sebagai contoh adalah adanya peta online sebuah kota dimana pengguna dapat dengan mudah mencari lokasi yang diinginkan secara online melalui jaringan intranet/internet tanpa mengenal batas geografi penggunanya. Secara umum Sistem Informasi Geografis dikembangkan berdasarkan pada prinsip masukan data, manajemen, analisis, dan representasi data.

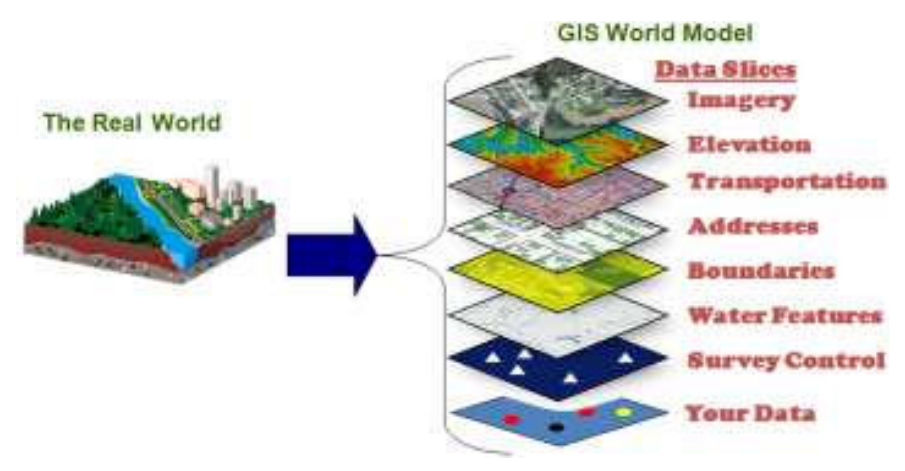

Gambar 1 Model GIS

\section{Web GIS}

Web GIS adalah suatu sistem yang dapat terhubung ke dalam jaringan internet yang digunakan untuk mengumpulkan, menyimpan, dan menampilkan data informasi bergeoreferensi atau data yang mengidentifikasikan lokasi objek tanpa adanya kebutuhan penggunaan software SIG

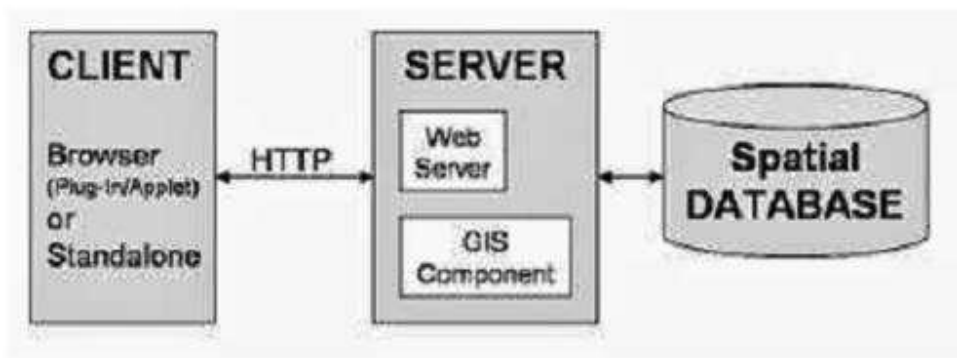

Gambar 2 Arsitektur Webgis 
Gambar di atas menunjukan arsitektur minimum sebuah sistem webgis. Aplikasi di sisi client yang berkomunikasi dengan server sebagai penyedia data melalui web protokol seperti HTTP (Hyper Text Transfer Protokol). Untuk menampilkan dan berinterasi dengan data SIG sebuah browser membutuhkan plug-in atau java applet dan bahkan keduanya. Web server bertanggung jawab terhadap proses permintaan dari client dan mengirimkan tenggapan terhadap respon tersebut. Dalam arsitektur web, sebuah web server juga mengatur komunikasi dengan server side SIG komponen.

Berdasarkan teknologi dan implementasinya, sistem informasi geografis dapat dikategorikan dalam tiga aplikasi yaitu SIG berbasis desktop (desktop GIS), SIG berbasis web (web GIS), dan SIG berbasis mobile (mobile GIS). Meskipun demikian, ketiganya saling berhubungan satu sama lain.

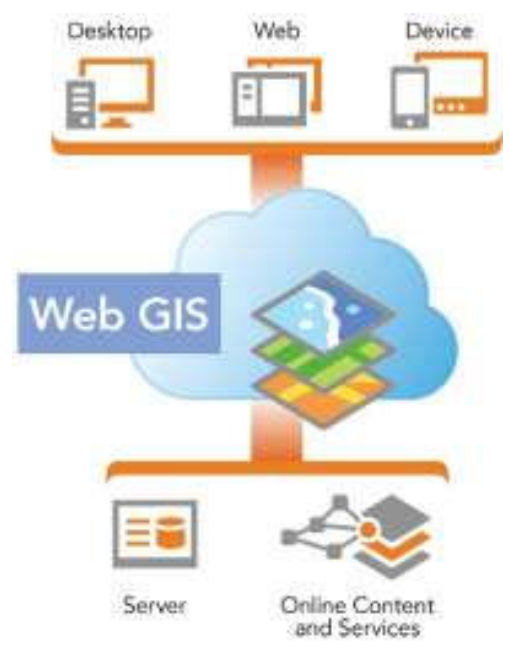

Gambar 3. Tiga Aplikasi GIS berdasarkan teknologi dan implementasinya

\section{Mobile GIS}

Mobile GIS merupakan integrasi antara beberapa teknologi, yaitu :

a. Perangkat Mobile

b. Global Positioning System (GPS)

c. Wireless communication untuk mengakses Internet GIS.

Dengan kombinasi dari beberapa teknologi di atas membuat mobile GIS dapat digunakan untuk menangkap, menyimpan, update, manipulasi, analisis dan menampilkan informasi geografi secara tepat. Sehingga melalui teknologi tersebut juga dapat membuat basis data yang diakses oleh personil di lapangan secara langsung di segala tempat dan waktu. Sistem ini dapat menambah informasi secara real-time ke basis data dan aplikasinya dalam hal kecepatan akses, tampilan, dan penentuan keputusan. Mobile GIS menawarkan fleksibilitas yang besar, memungkinkan pengguna memperoleh hasil secara cepat sesuai dengan kebutuhan mereka. Mobile GIS menyediakan akses data dari segala tempat dan di kapanpun keberadaan pengguna. Adapun beberapa komponen yang bergabung membentuk mobile GIS, yaitu mobile client, jaringan tanpa kabel, dan server. Mobile client berupa perekam data posisi misalnya GPS, yang mana pergerakan mobile dengan GPS yang diperoleh dan dengan GSM dapat mengirimkan posisi geografis ke server atau dalam kondisi lain dimana orang yang membawa smartphone yang di dalamnya sudah terinstal sistem operasi tertentu seperti dengan dilengkapi GPS. 
Smartphone tersebut dapat menunjukkan peta digital beserta koordinatnya dengan mengkomunikasikan dengan server melalui jaringan tanpa kabel. Jaringan tersebut dapat melalui Global System for Mobile Communication (GSM),

General Pocket Radio System (GPRS), Code Division Multiple Access (CDMA) yang mendukung transmisi digital.

\section{Pendekatan dan Metodologi}

\subsection{Metodologi Pelaksanaan Pekerjaan}

Tahapan-tahapan untuk menyelesaikan masalah terkait dengan Pembuatan Sistem Informasi Perencanaan Pemanfaatan dan Pengendalian Ruang menggunakan tahapantahapan analisa kebutuhan dan pengembangan sistem sebagai berikut:

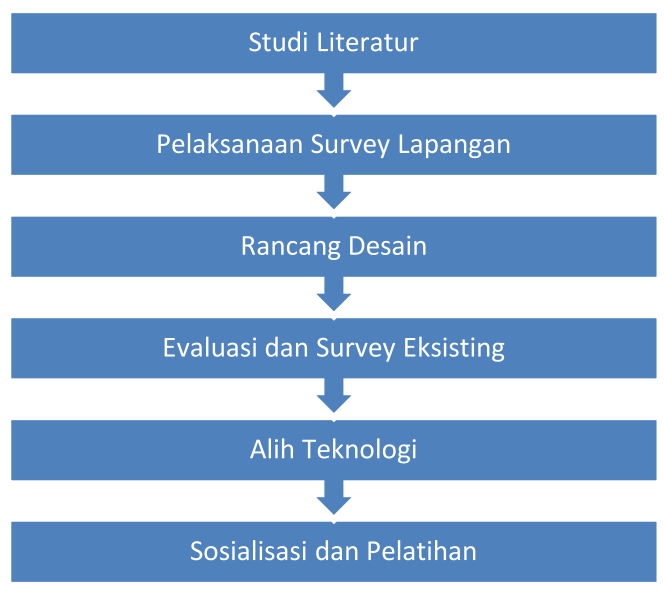

Gambar 4. Metodologi Pekerjaan

Pengembangkan sistem informasi perencanaan pemanfaatan dan pengendalian ruang menyajikan data yang akan ditampilkan terbagi menjadi 2 bagian yaitu:

a. Penyajian data dalam bentuk tabel yang berisikan data-data IPPT, IMB, Pengawasan dan pengendalian berupa jumlah, lokasi, jenis kegiatan. Data tabel ini untuk melihat data IPPT, IMB dan Pengawasan dan pengendalian dalam bentuk table dan visual.

b. Penyajian data dalam bentuk peta SIG yang berisikan Sistem Informasi Geografis untuk melihat tampilan peta-peta

c. Penyajian menu yang berisikan informasi yang berisikan data Wasdal/Pelanggaran, Registrasi Data Wasdal, Cari Lokasi dan Data Satpol PP

d. Penyajian data Pelaporan yang berisikan informasi IPPT Entry List, IMB Entry List dan Wasdal Entry List.

\subsubsection{Metode Studi Literatur}

Analisis kebutuhan perangkat keras dalam membangun aplikasi yaitu. 
Kajian studi literatur dilakukan dengan tujuan untuk memperoleh data dan informasi terkait konsep dasar informasi perencanaan pemanfatan dan pengendalian ruang. Berikut ini disampaikan metoda studi literatur berikut dengan hasil yang akan diperoleh dari kajian tersebut.

a. Kajian Perundangan: penelusuran pengaturan sistem informasi perencanaan pemanfatan dan pengendalian ruang yang memuat:

1) Penyelenggaraan perencanaan pemanfatan dan pengendalian ruang.

2) Perlunya sistem informasi perencanaan pemanfatan dan pengendalian ruang.

3) Tujuan sistem informasi perencanaan pemanfatan dan pengendalian ruang.

4) Kegunaan sistem informasi perencanaan pemanfatan dan pengendalian ruang.

5) Metoda pelaksanaan survey lapangan/primer untuk mengkaji ulang PROSES PENERBITAN IPPT dan IMB yang berkaitan dengan Kebutuhan Software bagi PENGGUNA (USER)

b. Kajian Literatur: penelusuran literatur-literatur terkait dengan teori dasar database dan pengembangan software yang memuat:

1) Pengembangan dan peranan sistem teknologi informasi saat ini dan ada saja kendala yang dihadapi dalam sistem teknologi informasi.

2) Tahapan pengembangan sistem informasi khususnya dalam pengembangan perangkat lunak disertai dengan parameter-parameter apa saja yang harus dipersiapkan.

3) Pengertian sistem informasi perencanaan pemanfatan dan pengendalian ruang berbasis Sistem Informasi Geografis.

\subsubsection{Arsitektur Sistem Informasi Perencanaan Pemanfaatan dan Pengendalian Ruang}

Setelah melakukan Survey evaluasi sistem eksisting, maka perlu dilakukan pengembangan dalam penambahan data informasi maupun peta.

Dalam Kerangka acuan Kerja, berisi tentang pengembangan Aplikasi berupa:

a. Database yang terhubung dengan SMART

b. Informasi peruntukan ruang :

1) Tersedianya fasilitas delineasi lokasi pada peta

2) Tersedianya fasilitas peta informasi peruntukan ruang, untuk dapat dicetak

c. Aplikasi android:

1) Aplikasi dapat digunakan oleh masyarakat untuk mengetahui zonasi RTRW

2) Aplikasi dapat digunakan oleh pemerintah untuk melakukan survey lokasi baik perizinan maupun pengawasan, khususnya penetapan posisi dan dokumentasi

d. Dokumentasi perizinan dan pengawasan :

Tersedianya fasilitas dokumentasi dokumen pendukung perizinan dan pengawasan baik berupa pdf maupun foto 
e. Website, dapat menampilkan informasi : Berita, OPD, Produk Hukum, Perencanaan, Pemanfaatan, Pengendalian dan Pelaporan

Untuk mengaplikasikan perangkat lunak dan database pada sistem informasi perencanaan pemanfaatan dan pengendalian ruang ini perlu dilakukan pengembangan dan pendalaman terhadap alur proses serta alih teknologi dapat dilakukan dengan workshop/training/ pelatihan dari sistem yang dibentuk agar dapat dioperasikan oleh user/pengguna jasa dan ditindaklanjuti dengan pengambilan data untuk masa-masa yang akan datang terutama proses yang berkaitan dengan pemanfaatan ruang.

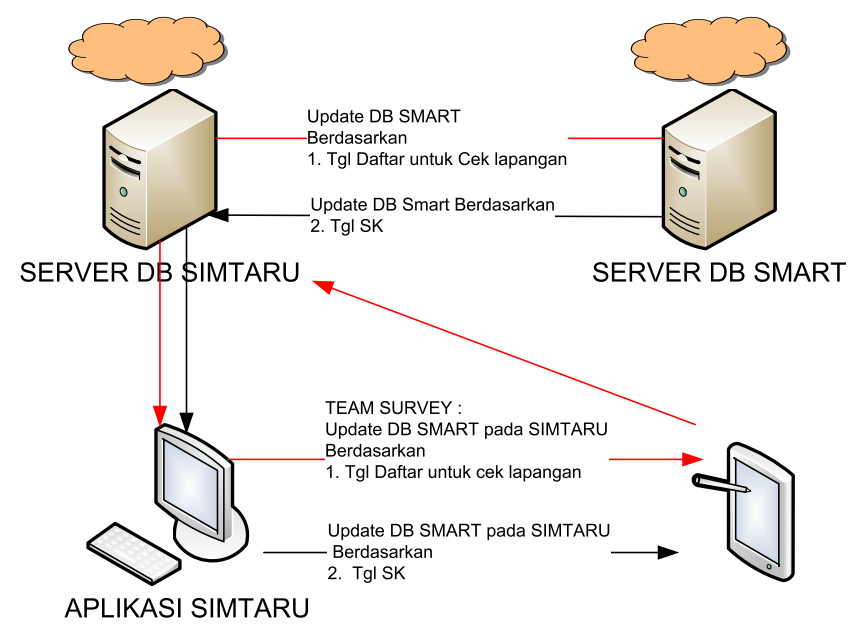

Gambar 5. Rencana Pengembangan Aplikasi

Sistem Informasi Perencanaan Pemanfaatan dan Pengendalian Ruang

\subsection{Rencana Pengembangan Aplikasi}

\subsubsection{Rancangan Kebutuhan Pengembangan Aplikasi}

Awal perancangan Aplikasi SIP3R dimulai dengan melakukan analisis dokumen berdasarkan hasil pengumpulan data berupa questioner dan wawancara yang telah djabarkan pada sub bab sebelumnya. Analisis dokumen bertujuan untuk mengetahui spesifikasi informasi yang ada dalam sistem.

\subsubsection{Analisis Sub Sistem Aplikasi Sistem Informasi Perencanaan Pemanfaatan dan Pengendalian Ruang}

Aplikasi Sistem Informasi Perencanaan Pemanfaatan dan Pengendalian Ruang merupakan kumpulan dari subsistem yang saling bekerjasama dalam mengelola data IMB dan IPPT. Kumpulan Subsistem Aplikasi Sistem Informasi Perencanaan Pemanfaatan dan Pengendalian Ruang terdiri dari :

a. Sub Sistem Input Data : Sub sistem ini berfungsi untuk melakukan proses pencatatan dan penyimpanan data ke database Sistem Informasi Perencanaan Pemanfaatan dan Pengendalian Ruang. Pada proses pencatatan semua data dikumpulkan dari entitas pengguna. 


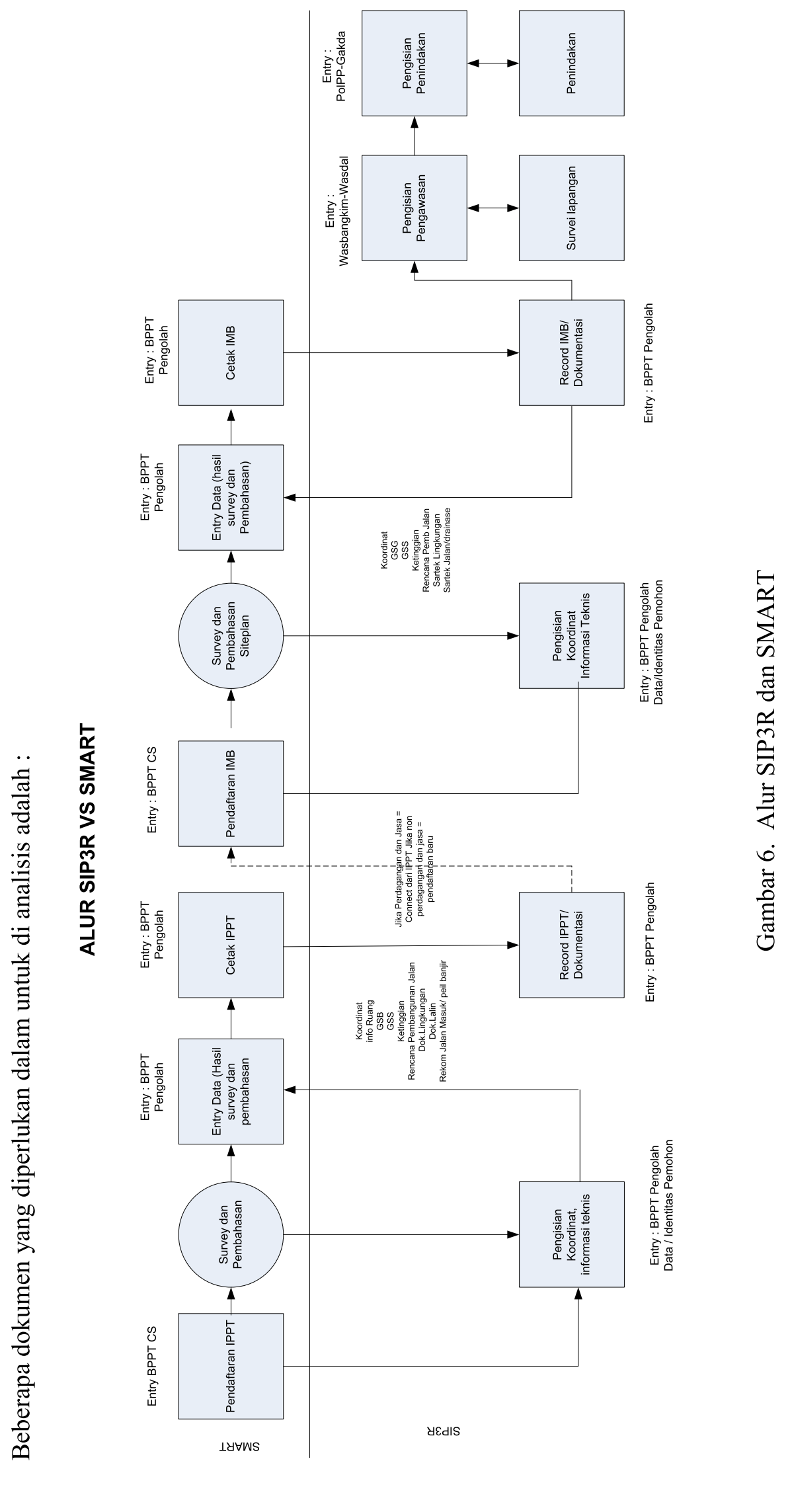


b. Sub Sistem Output : Sub sistem ini berfungsi untuk menghasilkan seluruh laporan atau output dari proses pencatatan dan transaksi yang dilakukan oleh entitas pengguna. Output yang dihasilkan dari subsistem ini dapat berupa softcopy maupun hardcopy seperti : tabel dan grafik

c. Subsistem Basis Data: Sub sistem ini berfungsi menentukan data apa yang disimpan dan dihasilkan dari proses oleh aplikasi Sistem Informasi Perencanaan Pemanfaatan dan Pengendalian Ruang. Selain itu, subsistem ini juga melakukan manipulasi dan permodelan data untuk menghasilkan informasi yang diharapkan.

d. Subsistem Jaringan Data : Subsistem ini behubungan erat dengan pengiriman dan komunikasi data antara entitas pengguna.

\subsubsection{Use Case Diagram Aplikasi SIP3R}

Use case merupakan pemodelan untuk kelakuan (behavior) sisteminformasi yang akan dibuat. Use case mendeskripsikan sebuah interaksi antara satu atau lebih aktor dengan sistem. Sebagaimana penjelasan diatas use case diagram secara keseluruhan sistem dapat digambarkan sebagai berikut ini:

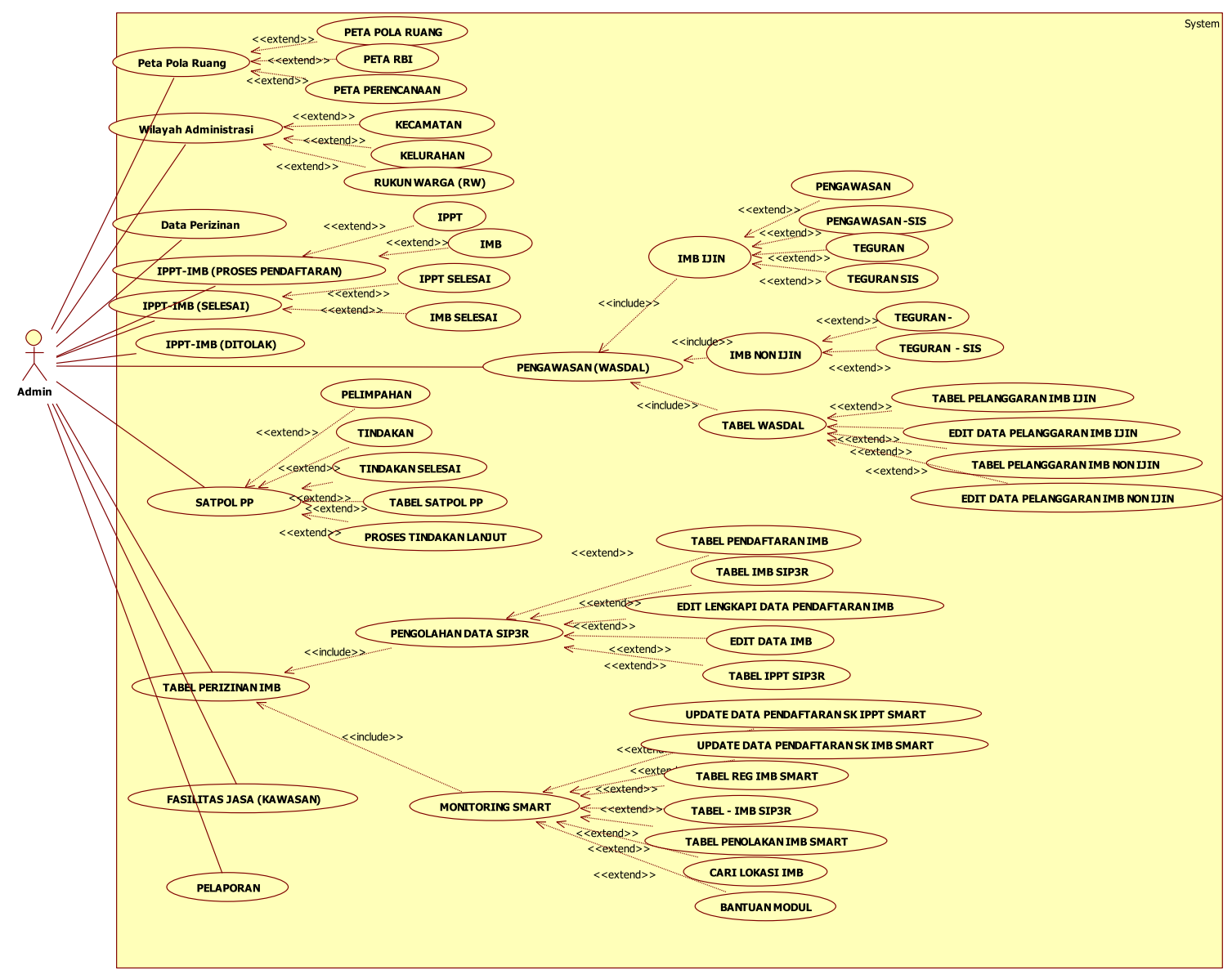

Gambar 7. Use Case Diagram 


\subsubsection{Sequence Diagram}

a. Sequence Diagram Pengolahan Data IMB

Sequence Diagram pengolahan data IMB pada aplikasi menggambarkan alur data yang dicatat oleh sistem dan di simpan dalam database sesuai dengan user dari Aplikasi, dapat dilihat pada gambar berikut ini :

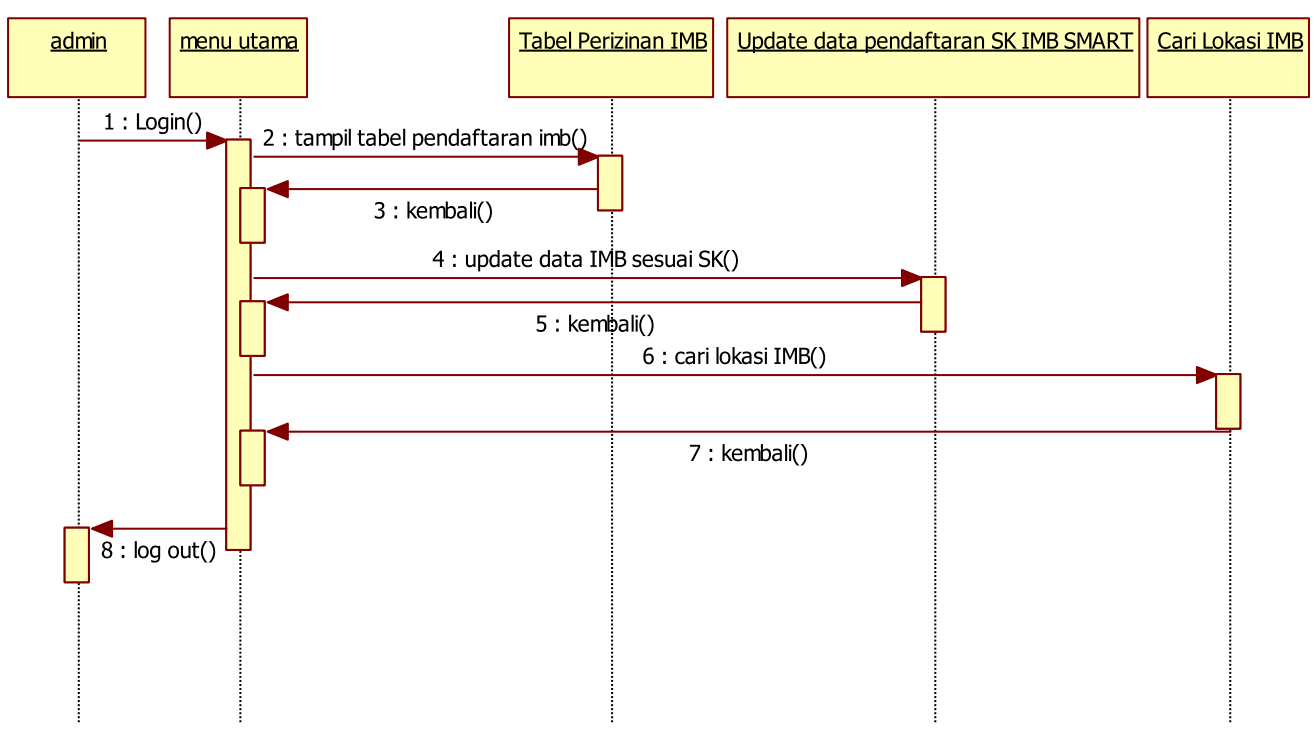

Gambar 8. Sequence Diagram Pengolahan Data IMB

b. Sequence Diagram Pengolahan Data IPPT

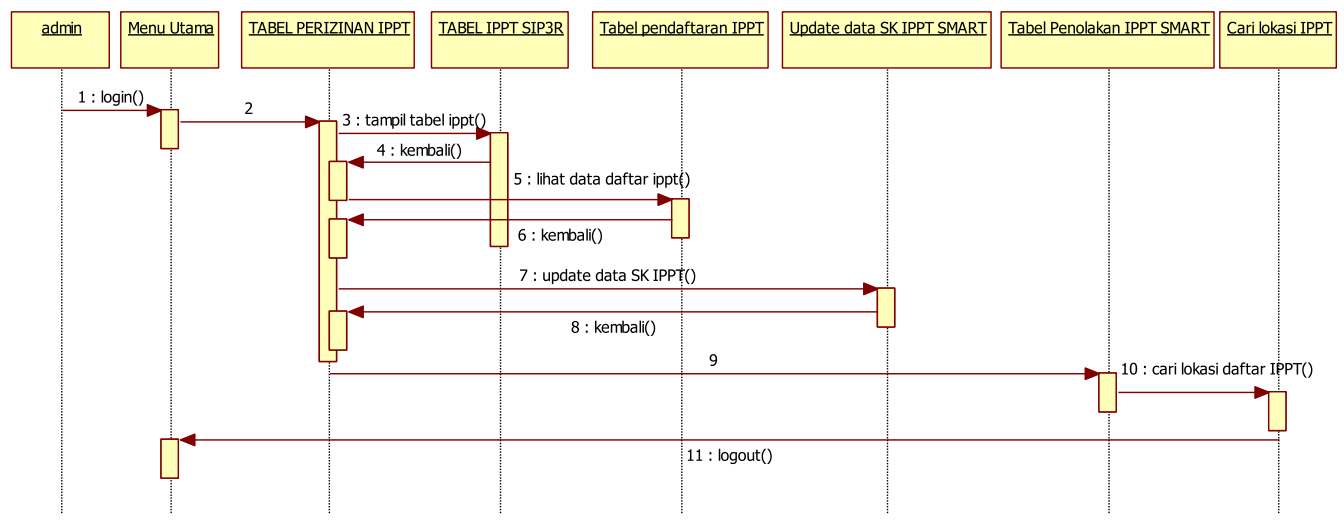

Gambar 8. Sequence Diagram Pengolahan Data IPPT

c. Sequence Diagram Pengolahan Data Wasdal 


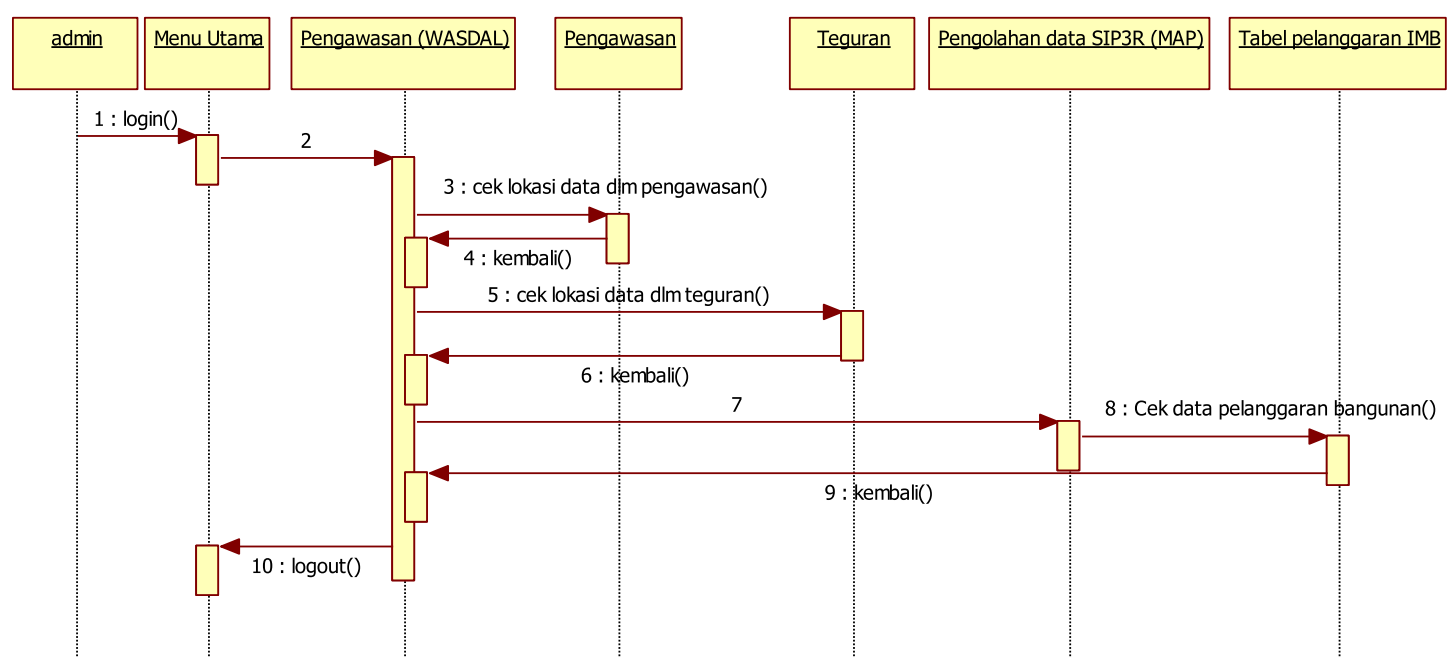

Gambar 9. Sequence Diagram Pengolahan Data WASDAL

d. Sequence Diagram Pengolahan Data Satpol PP

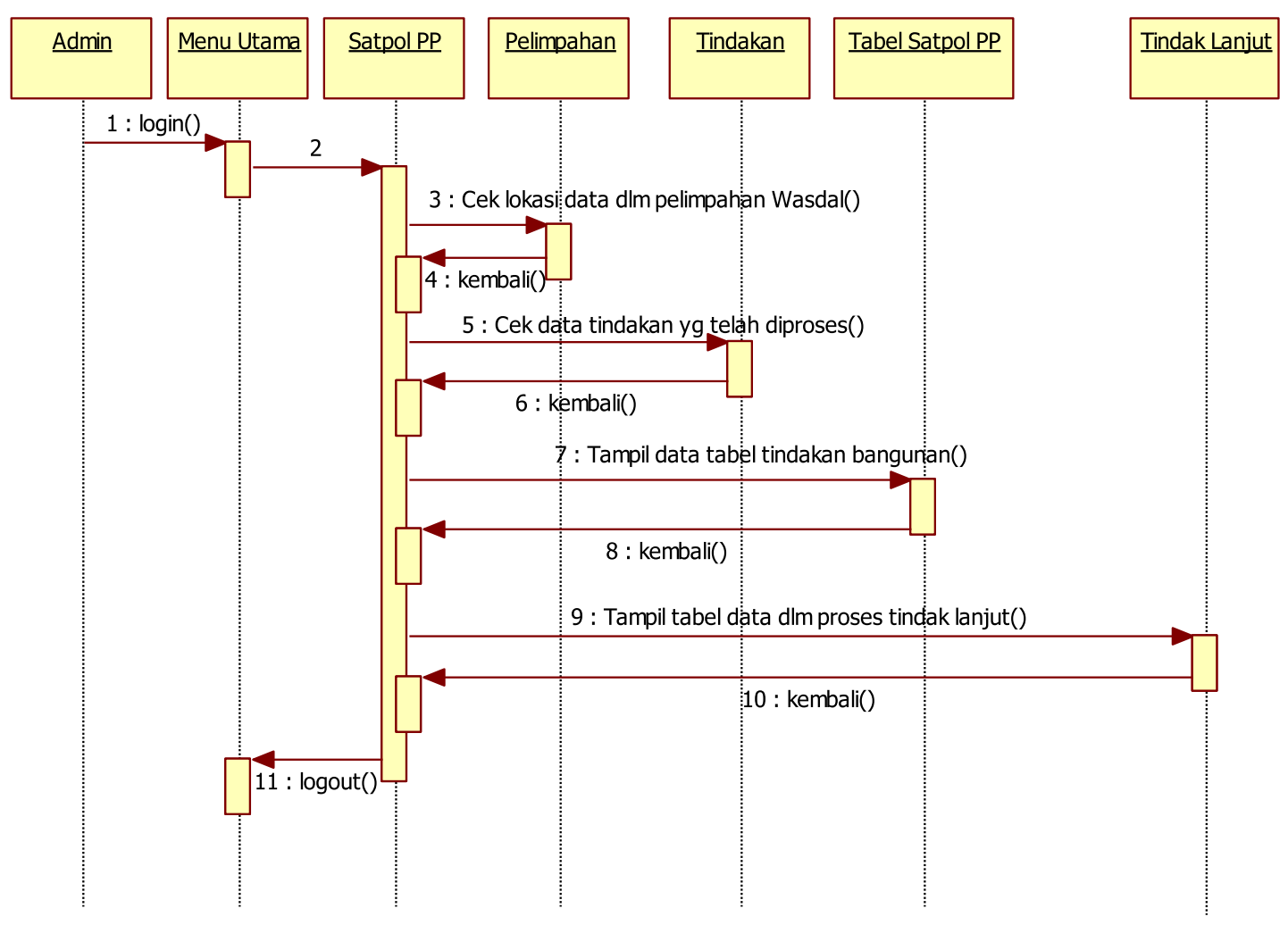

Gambar 10. Sequence Diagram Pengolahan Data Satpol PP 


\subsubsection{Rancangan antar muka Aplikasi}

Rancangan struktur menu Aplikasi harus dibuat jelas dan mudah dimengerti oleh pengguna. Fasilitas dan struktur menu terdiri dari :

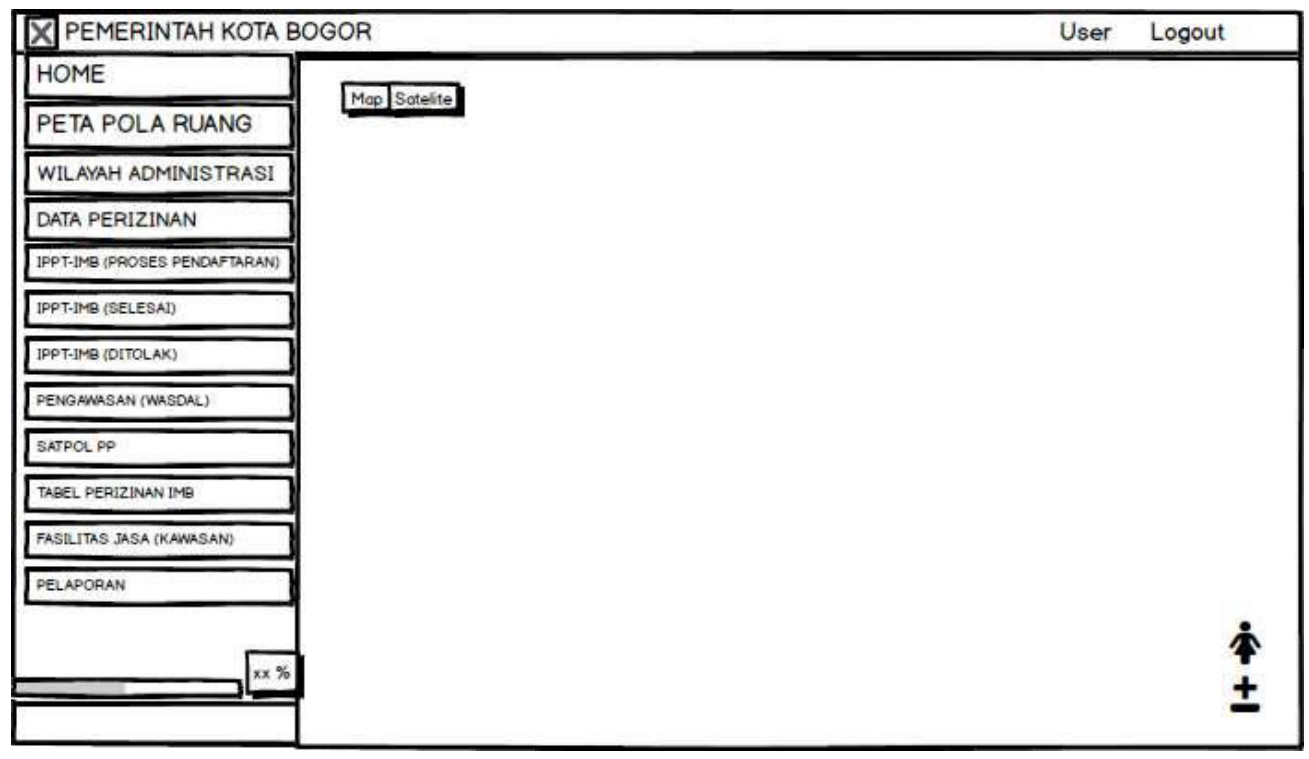

Gambar 11. Rancangan Halaman Menu Utama

\begin{tabular}{|c|}
\hline HOME \\
\hline PETA POLA RUANG \\
\hline$-X X X X X \quad X X X X X X X X$ \\
\hline$\square \quad$ Peta Pola Ruang \\
\hline$\square \quad$ Peta RBI \\
\hline Peta Perencanaan \\
\hline I CARI KOORD \\
\hline WILAYAH ADMINISTRASI \\
\hline$\square$ Kecamatan \\
\hline$\square \square$ Kelurahan \\
\hline$\square \square$ Rukun Wargo (RW) \\
\hline DATA PERIZINAN \\
\hline PPT-IMB (PROSES PENDAFTARAN) \\
\hline
\end{tabular}

Gambar 12. Rancangan Halaman SubMenu Peta Pola Ruang dan Wilayah Administrasi 


\begin{tabular}{|c|}
\hline DATA PERIZINAN: \\
\hline IPPT - IMB (PROSES PENDAFTARAN) \\
\hline \\
\hline IPPT \\
\hline IMB \\
\hline IPPT - IMB (SELESAI) \\
\hline \\
\hline OIPPT \\
\hline IMB \\
\hline IPPT - IMB (DITOLAK) \\
\hline
\end{tabular}

Gambar 13. Rancangan Halaman SubMenu Data Perizinan

\begin{tabular}{|l|}
\hline \multicolumn{1}{|c|}{ TABEL PERIZINAN IMB } \\
\hline PENGOLAHAN DATA SIP3R \\
\hline TABEL PENDAFTARAN IMB \\
\hline TABEL IMB SIP3R \\
\hline EDIT LENGKAPI DATA PENDAFTARAN IMB \\
\hline EDIT DATA IMB \\
\hline TABEL IPPT SIP3R \\
\hline \\
\hline MONITORING SMART \\
\hline UPDATE PENDAFTARAN -SK IPPT SMART \\
\hline UPDATE PENDAFTARAN -SK IMB SMART \\
\hline TABEL REG IMB SMART \\
\hline TABEL IMB SIP3R \\
\hline TABEL PENOLAKAN IMB SMART \\
\hline CARI LOKASI IMB \\
\hline BANTUAN MODUL \\
\hline
\end{tabular}

Gambar 14. Rancangan Halaman SubMenu Tabel Perizinan IMB dan Monitoring SMART

\begin{tabular}{|l|}
\hline TABEL PERIZINAN IPPT \\
\hline SIP3R \\
\hline TABEL IPPT SIP3R \\
\hline TABEL PENDAFTARAN IPPT \\
\hline EDIT-LENGKAPI DATA PENDAFTARAN IPPT \\
\hline MONITORING SMART \\
\hline UPDATE DATA PENDAFTARAN-SK IPPT SMART \\
\hline TABEL PENOLAKAN IPPT SMART \\
\hline CARI LOKASI IPPT SMART \\
\hline BANTUAN MODUL \\
\hline
\end{tabular}

Gambar 15. Rancangan SubMenu Tabel Perizinan IPPT 


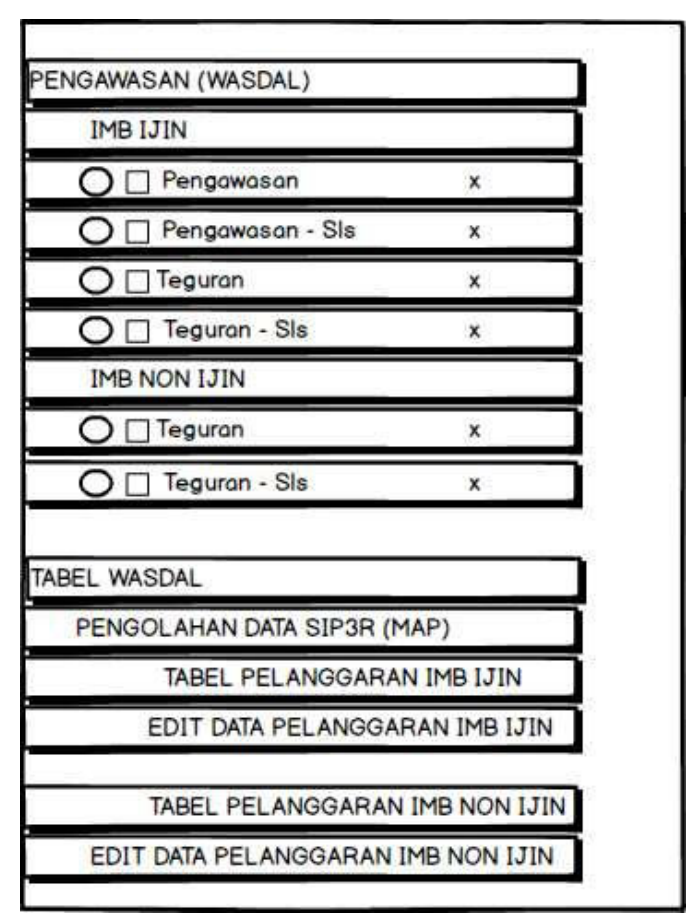

Gambar 16. Rancangan Halaman SubMenu Pengawasan (WASDAL)

\begin{tabular}{|l|}
\hline SATPOL PP \\
\hline $\mathrm{O} \square$ Pelimpahan \\
\hline $\mathrm{O} \square$ Tindakan \\
\hline $\mathrm{O} \square$ Tindakan Selesai \\
\hline \\
\hline TABEL SATPOL PP \\
\hline TABEL SATPOLPP \\
\hline PROSES TINDAK LANJUT \\
\hline BANTUAN MODUL \\
\hline
\end{tabular}

Gambar 17. Rancangan Halaman SubMenu PENINDAKAN DAN TABEL

Tabel 1. Rancangan Antar Muka

\begin{tabular}{|c|c|c|}
\hline Menu & Sub Menu & Fungsi \\
\hline \multirow[t]{5}{*}{$\begin{array}{l}\text { PETA POLA } \\
\text { RUANG }\end{array}$} & $\begin{array}{l}\text { Peta Pola } \\
\text { Ruang }\end{array}$ & Menampilkan Pola Ruang Kota Bogor \\
\hline & Peta RBI & Menampilkan Peta RBI (BIG) \\
\hline & $\begin{array}{l}\text { Peta } \\
\text { Perencanaan }\end{array}$ & \\
\hline & Cari Koord & $\begin{array}{l}\text { Menampilkan Pencarian Koordinat Lokasi } \\
\text { yang di inginkan }\end{array}$ \\
\hline & Kecamatan & Menampilkan informasi batas kecamatan \\
\hline
\end{tabular}




\begin{tabular}{|c|c|c|}
\hline Menu & Sub Menu & Fungsi \\
\hline \multirow{2}{*}{$\begin{array}{l}\text { WILAYAH } \\
\text { ADMINISTRASI }\end{array}$} & IV. KELURAHAN & Menampilkan informasi batas kelurahan \\
\hline & $\begin{array}{l}\text { Rukun Warga } \\
\text { (RW) }\end{array}$ & Menampilkan informasi batas RW \\
\hline \multirow[t]{3}{*}{$\begin{array}{l}\text { DATA } \\
\text { PERIZINAN }\end{array}$} & $\begin{array}{l}\text { IPPT-IMB } \\
\text { (PROSES } \\
\text { PENDAFTARAN) }\end{array}$ & $\begin{array}{l}\text { Menampilkan informasi Lokasi Data } \\
\text { Pendaftaran IPPT dan IMB dan Jml Data } \\
\text { Pendaftaran IPPT dan IMB }\end{array}$ \\
\hline & $\begin{array}{l}\text { IPPT-IMB } \\
\text { (SELESAI) }\end{array}$ & $\begin{array}{l}\text { Menampilkan informasi Lokasi Data IPPT } \\
\text { dan IMB selesai dan Jml Data IPPT dan IMB } \\
\text { selesai }\end{array}$ \\
\hline & $\begin{array}{l}\text { IPPT-IMB } \\
\text { (DITOLAK) }\end{array}$ & \\
\hline \multirow[t]{12}{*}{$\begin{array}{l}\text { TABEL } \\
\text { PERIZINAN IMB }\end{array}$} & $\begin{array}{l}\text { TABEL } \\
\text { PENDAFTARAN } \\
\text { IMB }\end{array}$ & Menampilkan Tabel Pendaftaran IMB \\
\hline & $\begin{array}{l}\text { TABEL IMB } \\
\text { SIP3R }\end{array}$ & Menampilkan Tabel IMB \\
\hline & $\begin{array}{l}\text { EDIT LENGKAPI } \\
\text { DATA } \\
\text { PENDAFTARAN } \\
\text { IMB }\end{array}$ & \\
\hline & EDIT DATA IMB & \\
\hline & $\begin{array}{l}\text { TABEL IPPT } \\
\text { SIP3R }\end{array}$ & Menampilkan Tabel IPPT \\
\hline & $\begin{array}{l}\text { UPDATE DATA } \\
\text { PENDAFTARAN } \\
\text { SK IPPT SMART }\end{array}$ & $\begin{array}{l}\text { Melakukan Update data Pendaftaran IMB } \\
\text { dan data IPPT sesuai tanggal Pendaftaran } \\
\text { atau tanggal Terbut SK IPPT (Sama dengan } \\
\text { Proses Update IMB) }\end{array}$ \\
\hline & $\begin{array}{l}\text { UPDATE DATA } \\
\text { PENDAFTARAN } \\
\text { SK IMB SMART }\end{array}$ & $\begin{array}{l}\text { Melakukan Update data Pendaftaran IMB } \\
\text { dan data IMB sesuai tanggal Pendaftaran } \\
\text { atau tanggal Terbut SK IMB (Sama dengan } \\
\text { Proses Update IPPT) }\end{array}$ \\
\hline & $\begin{array}{l}\text { TABEL REG IMB } \\
\text { SMART }\end{array}$ & \\
\hline & $\begin{array}{l}\text { TABEL IMB } \\
\text { SIP3R }\end{array}$ & Menampilkan Tabel IMB \\
\hline & $\begin{array}{l}\text { TABEL } \\
\text { PENOLAKAN } \\
\text { IMB SMART }\end{array}$ & \\
\hline & $\begin{array}{l}\text { CARI LOKASI } \\
\text { IMB }\end{array}$ & $\begin{array}{l}\text { Untuk melakukan pencarian lokasi } \\
\text { Pendaftaran IPPT maupun IMB } \\
\text { berdasarkan Data lokasi yang ada }\end{array}$ \\
\hline & $\begin{array}{l}\text { BANTUAN } \\
\text { MODUL }\end{array}$ & Menampilkan infomasi Modul IMB \\
\hline
\end{tabular}




\begin{tabular}{|c|c|c|}
\hline Menu & Sub Menu & Fungsi \\
\hline \multirow{7}{*}{$\begin{array}{l}\text { TABEL } \\
\text { PERIZINAN } \\
\text { IPPT }\end{array}$} & $\begin{array}{l}\text { TABEL IPPT } \\
\text { SIP3R }\end{array}$ & Menampilkan Tabel IPPT \\
\hline & $\begin{array}{l}\text { TABEL } \\
\text { PENDAFTARAN } \\
\text { IPPT }\end{array}$ & $\begin{array}{l}\text { Menampilkan Tabel } \\
\text { Pendaftaran IPPT }\end{array}$ \\
\hline & $\begin{array}{l}\text { EDIT LENGKAPI } \\
\text { DATA } \\
\text { PENDAFTARAN } \\
\text { IPPT }\end{array}$ & \\
\hline & $\begin{array}{l}\text { UPDATE DATA } \\
\text { PENDAFTARAN } \\
\text { SK IPPT SMART }\end{array}$ & $\begin{array}{l}\text { Melakukan Update data Pendaftaran IPPT } \\
\text { dan data SK IPPT sesuai tanggal } \\
\text { Pendaftaran atau tanggal Tersebut SK IPPT } \\
\text { (Sama dengan Proses Update IMB) }\end{array}$ \\
\hline & $\begin{array}{l}\text { TABEL } \\
\text { PENOLAKAN } \\
\text { IPPT SMART }\end{array}$ & \\
\hline & $\begin{array}{l}\text { CARI LOKASI } \\
\text { IPPT }\end{array}$ & $\begin{array}{l}\text { Untuk melakukan pencarian lokasi } \\
\text { Pendaftaran IPPT maupun IMB } \\
\text { berdasarkan Data lokasi yang ada }\end{array}$ \\
\hline & $\begin{array}{l}\text { BANTUAN } \\
\text { MODUL }\end{array}$ & Menampilkan infomasi Modul IPPT \\
\hline \multirow[t]{6}{*}{$\begin{array}{l}\text { PENGAWASAN } \\
\text { (WASDAL) }\end{array}$} & $\begin{array}{l}\text { IMB IJIN - } \\
\text { PENGAWASAN }\end{array}$ & $\begin{array}{l}\text { Menampilkan informasi Lokasi Data dalam } \\
\text { Proses Pengawasan untuk bangunan } \\
\text { memiliki IMB }\end{array}$ \\
\hline & $\begin{array}{l}\text { IMB IJIN - } \\
\text { PENGAWASAN- } \\
\text { Sls }\end{array}$ & $\begin{array}{l}\text { Menampilkan informasi Lokasi Data selesai } \\
\text { Proses Pengawasan untuk bangunan } \\
\text { memiliki IMB }\end{array}$ \\
\hline & $\begin{array}{l}\text { IMB IJIN - } \\
\text { TEGURAN }\end{array}$ & $\begin{array}{l}\text { Menampilkan informasi Lokasi Data dalam } \\
\text { Proses Teguran untuk bangunan memiliki } \\
\text { IMB }\end{array}$ \\
\hline & $\begin{array}{l}\text { IMB IJIN - } \\
\text { TEGURAN Sls }\end{array}$ & $\begin{array}{l}\text { Menampilkan informasi Lokasi Data dalam } \\
\text { Proses Teguran selesai untuk bangunan } \\
\text { memiliki IMB }\end{array}$ \\
\hline & $\begin{array}{l}\text { IMB NON IJIN - } \\
\text { Teguran }\end{array}$ & $\begin{array}{l}\text { Menampilkan informasi Lokasi Data dalam } \\
\text { Proses Teguran untuk bangunan tidak } \\
\text { memiliki IMB }\end{array}$ \\
\hline & $\begin{array}{l}\text { IMB NON IJIN - } \\
\text { Teguran SIs }\end{array}$ & $\begin{array}{l}\text { Menampilkan informasi Lokasi Data dalam } \\
\text { Proses Teguran selesai untuk bangunan } \\
\text { tidak memiliki IMB }\end{array}$ \\
\hline \multirow[t]{2}{*}{$\begin{array}{l}\text { TABEL } \\
\text { WASDAL }\end{array}$} & $\begin{array}{l}\text { Tabel } \\
\text { Pelanggaran } \\
\text { IMB IJIN }\end{array}$ & $\begin{array}{l}\text { Menampilkan Tabel Data Pelanggaran } \\
\text { bangunan memiliki IMB }\end{array}$ \\
\hline & $\begin{array}{l}\text { Edit Data } \\
\text { Pelanggaran } \\
\text { IMB }\end{array}$ & $\begin{array}{l}\text { Menampilkan Tabel Data Pelanggaran } \\
\text { bangunan memiliki IMB untuk dapat diedit }\end{array}$ \\
\hline
\end{tabular}




\begin{tabular}{|c|c|c|}
\hline \multirow[t]{3}{*}{ Menu } & Sub Menu & Fungsi \\
\hline & $\begin{array}{l}\text { Tabel } \\
\text { Pelanggaran } \\
\text { IMB NON IJIN }\end{array}$ & $\begin{array}{l}\text { Menampilkan Tabel Data Pelanggaran } \\
\text { bangunan tidak memiliki IMB }\end{array}$ \\
\hline & $\begin{array}{l}\text { Edit Data } \\
\text { Pelanggaran } \\
\text { NON IMB }\end{array}$ & $\begin{array}{l}\text { Menampilkan Tabel Data Pelanggaran } \\
\text { bangunan tidak memiliki IMB untuk dapat } \\
\text { diedit }\end{array}$ \\
\hline \multirow[t]{3}{*}{ SATPOL PP } & Pelimpahan & $\begin{array}{l}\text { Menampilkan lokasi Data dalam } \\
\text { Pelimpahan dari Wasdal }\end{array}$ \\
\hline & Tindakan & $\begin{array}{l}\text { Menampilkan Data Tindakan yang } \\
\text { sedang di proses oleh SatpolPP }\end{array}$ \\
\hline & $\begin{array}{l}\text { Tindakan } \\
\text { Selesai }\end{array}$ & $\begin{array}{l}\text { Data Tindakan yang sudah di proses oleh } \\
\text { Satpol PP }\end{array}$ \\
\hline \multirow[t]{3}{*}{$\begin{array}{l}\text { TABEL SATPOL } \\
\text { PP }\end{array}$} & Tabel Satpol PP & $\begin{array}{l}\text { Menampilkan Tabel Data Tindakan } \\
\text { bangunan yang memiliki ijin dan tidak } \\
\text { memiliki ijin }\end{array}$ \\
\hline & $\begin{array}{l}\text { Proses Tindak } \\
\text { Lanjut }\end{array}$ & $\begin{array}{l}\text { Tampilan Tabel dalam proses Tindakan dan } \\
\text { Tindak lanjut }\end{array}$ \\
\hline & Bantuan Modul & Menampilkan infomasi Modul Satpol PP \\
\hline
\end{tabular}

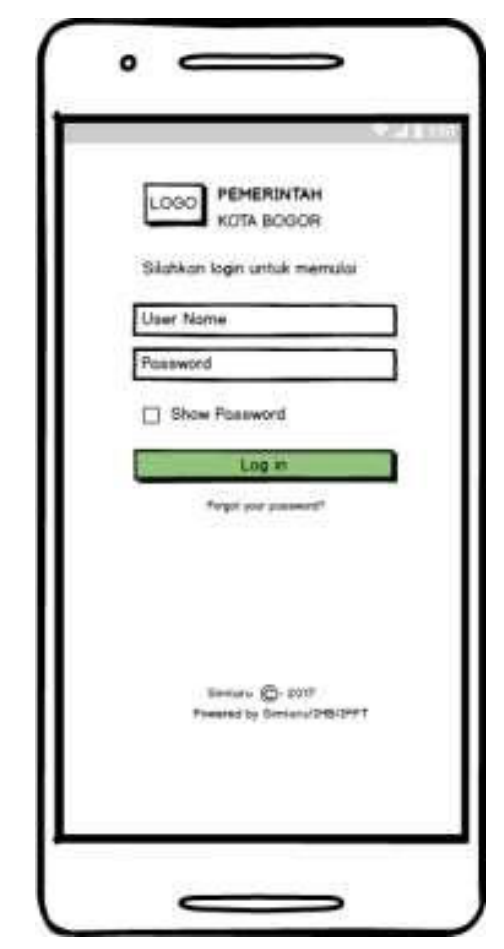

Gambar 18. Rancangan Tampilan Aplikasi Mobile untuk menentukan koordinat pendaftaran IMB 


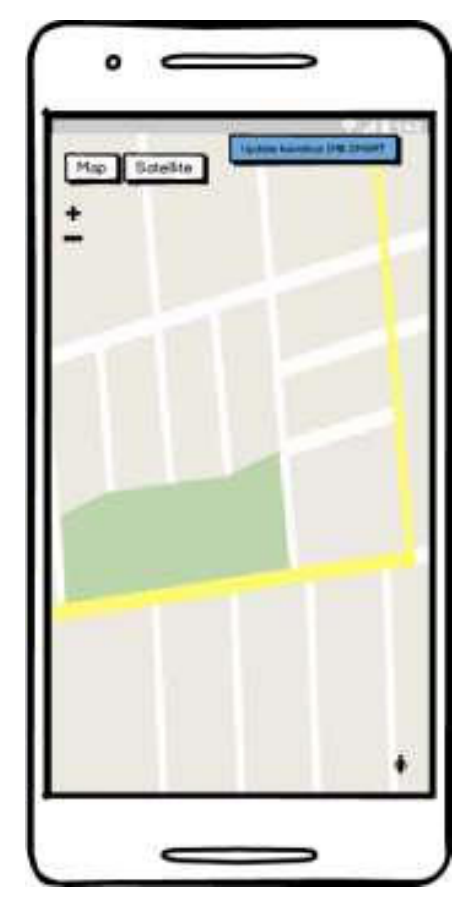

Gambar 19. Rancangan update kordinat pendaftaran IMB menggunakan aplikasi mobile

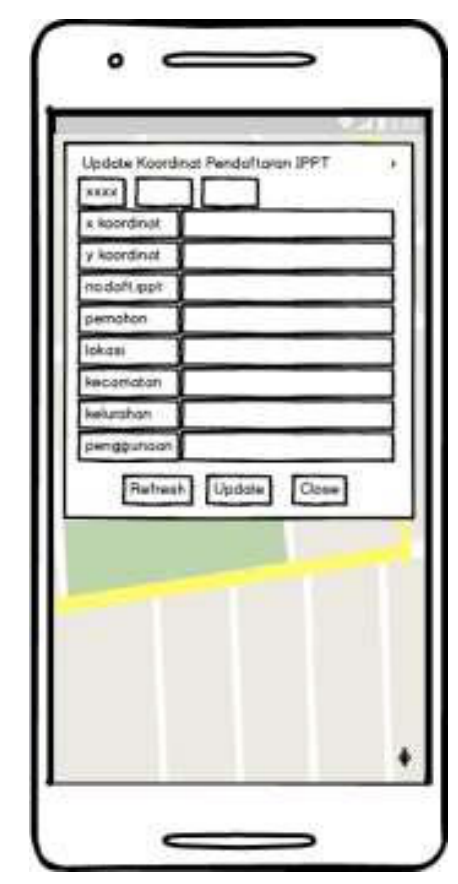

Gambar 20. Rancangan update kordinat pendaftaran IPPT menggunakan aplikasi mobile 


\section{Implementasi Aplikasi}

Aplikasi ini merupakan suatu Sistem Aplikasi berbasis teknologi informasi untuk mengelola data IMB dan IPPT yang memiliki penampungan/storage bersama untuk mengakomodasi informasi IMB dan IPPT agar terorganisir dan terjaga. Sistem ini digunakan untuk mengelola data IMB dan IPPT pada Badan Perencanaan Pembangunan Daerah Kota B dan setiap saat dapat dilakukan konsolidasi data keseluruhan secara otomatis.

Aplikasi ini merupakan aplikasi Web/Android yang terhubung dengan komputer jaringan lokal atau internet dan hanya memerlukan browser untuk dapat menjalankannya. Perangkat aplikasi yang digunakan :

a. Komputer : digunakan untuk melakukan updating data

b. Tablet (Hp) : digunakan untuk melakukan updating koordinat lokasi.

Prosedur tata cara penggunaan aplikasi ini dimulai dengan munculnya layar pembuka dengan menu halaman Login yang terdiri dari "User Name" dan "Password" sebagai autentifikasi.

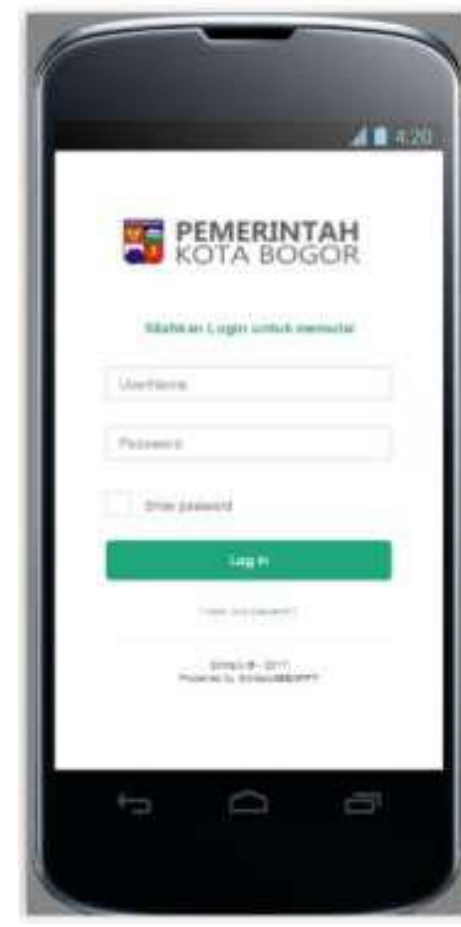

\section{Login Pengguna}

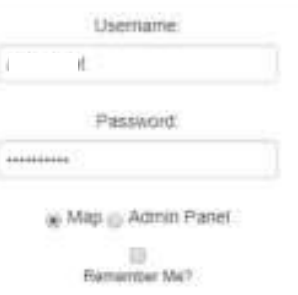

Gambar 21. Halaman Autentifikasi User

LOGIN : Di gunakan oleh pengguna pengolah data Aplikasi :

\section{IPPT}

2. IMB

3. Wasdal 


\section{Polpp}

Berikut tampilan home untuk user dengan akses level admin.

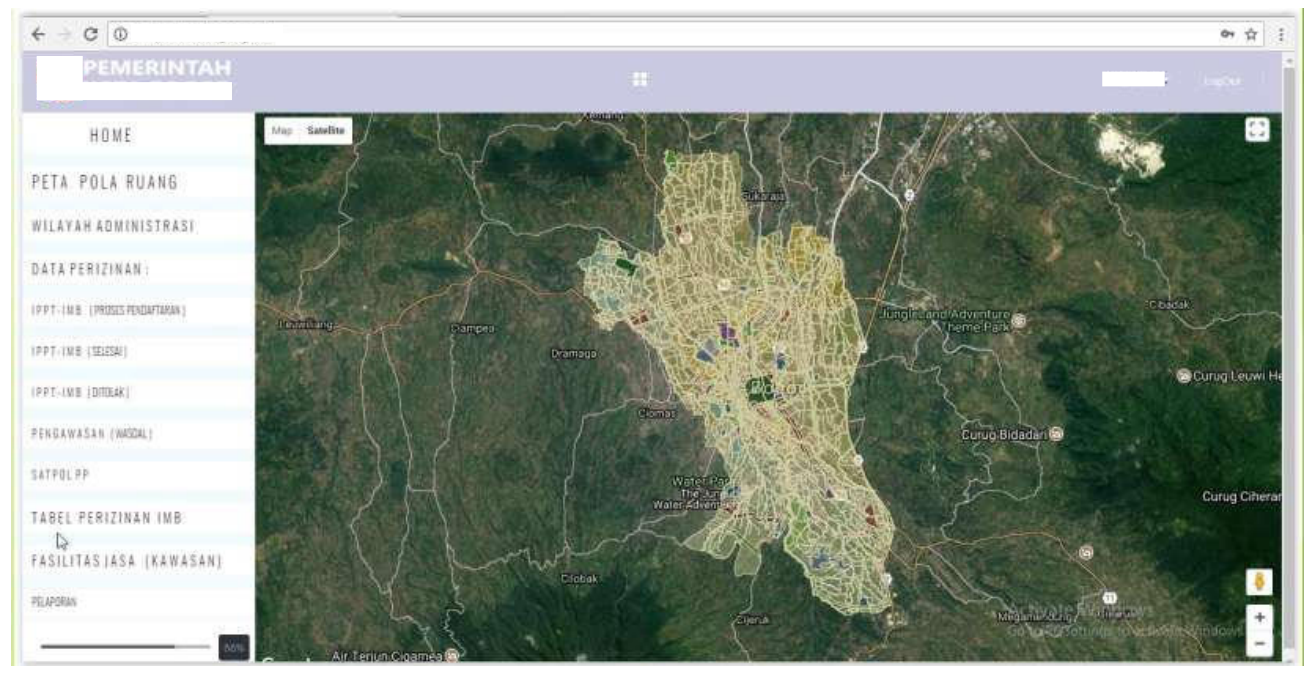

Gambar 22. Tampilan utama Aplikasi Level Admin

Pada menu utama Aplikasi ini terdapat beberapa menu dan sub menu.

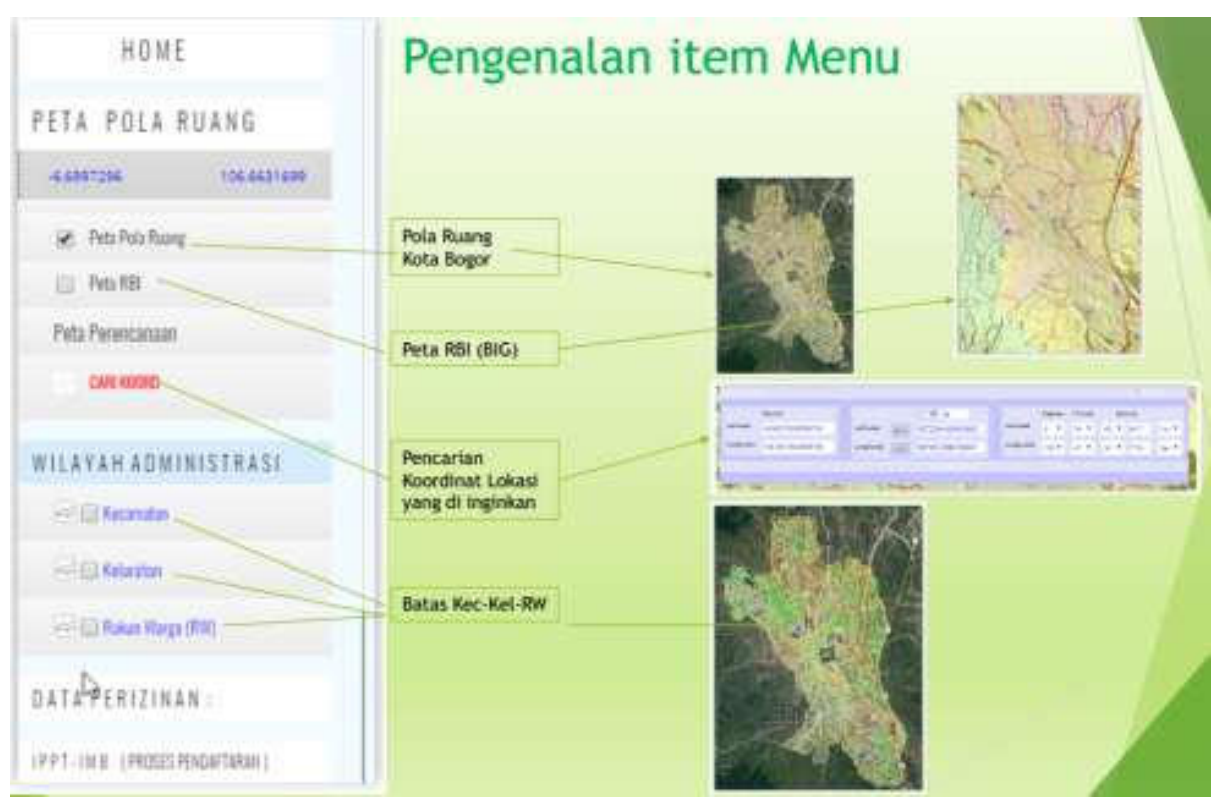

Gambar 23. Tampilan Menu dan Sub Menu

Sub menu Peta Pola Ruang dibuat untuk menyajikan informasi Pola Ruang Kota Bogor. Sub menu Wilayah Administrasi dibuat untuk menyajikan data batas wilayah Kecamatan, kelurahan dan Rukun Warga. 


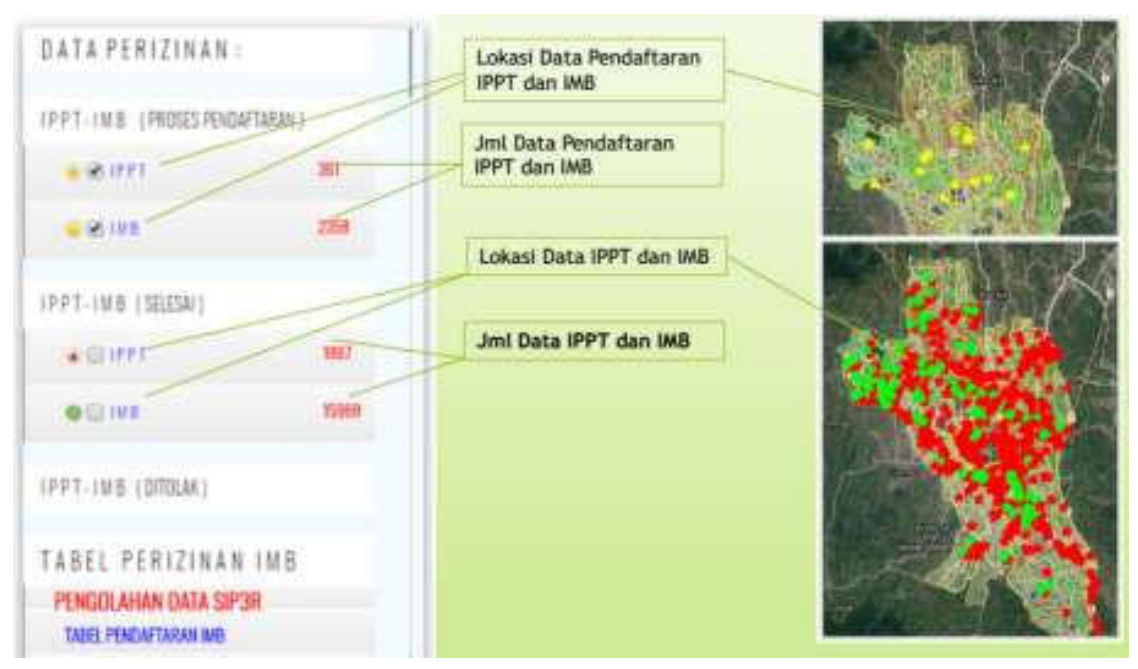

Gambar 24. Tampilan Sub Menu Perizinan

Tim survey dapat melakukan updating kordinat lokasi data atau record sesuai dengan no.pendaftaran dengan menggunakan aplikasi mobile pada Tablet atau Hp yang sudah di install software (imbreg) dan lakukan login user.

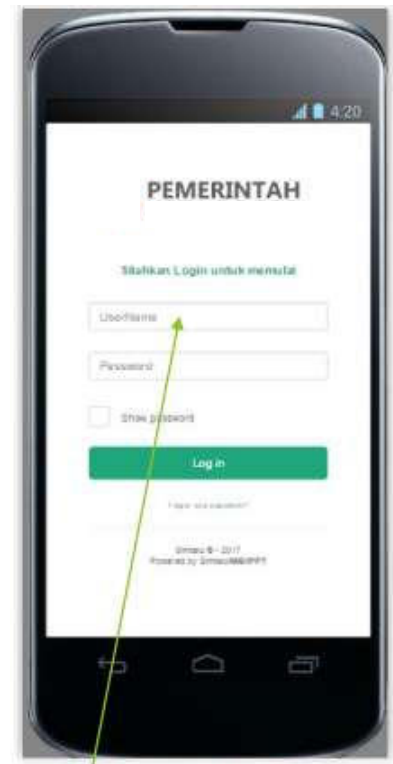

1.E.a. Login : User, Password

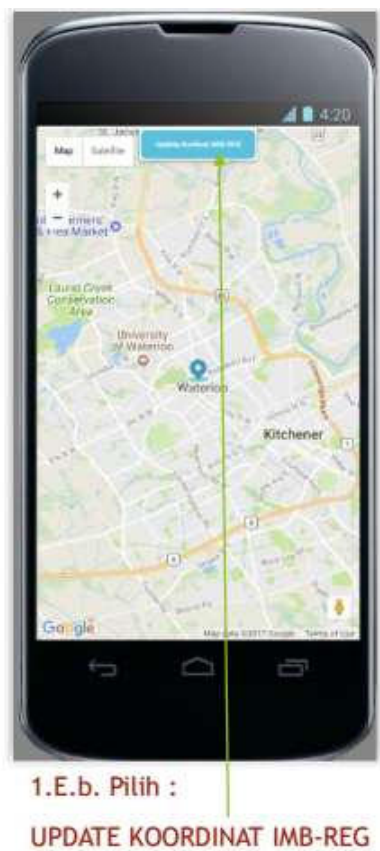

UPDATE KOORDINAT IMB-REG

Gambar 25. Tampilan Aplikasi mobile

\section{Kesimpulan dan Saran}

\subsection{Kesimpulan}

Sesuai dengan hasil analisa dan pembahasan yang telah dijabarkan pada pekerjaan ini, beberapa kesimpulan dapat diambil, sebagai berikut : 
1. Aplikasi database yang terhubung dengan SMART yang telah dibangun memiliki kelebihan dalam mempercepat proses pencarian, laporan dan informasi statistik data IMB, IPPT, WASDAL dan tindakan SATPOL PP, sehingga dapat menghemat waktu dan kesalahan.

2. Memberi kemudahan bagi BAPPEDA Kota B, karena telah memiliki fasilitas aplikasi android yang memudahkan untuk melakukan survey lokasi baik perizinan maupun pengawasan, khususnya dan dapat digunakan oleh masyarakat untuk mengetahui zonasi RTRW

3. Aplikasi yang dibuat memudahkan bagian terkait dalam hal membuat laporanlaporan, karena telah terformat dan terstruktur secara dinamis.

\subsection{Saran}

Berdasarkan kesimpulan di atas dapat diambil beberapa rekomendasi sebagai indikasi tidak lanjut yang harus dilakukan dalam rangka implementasi dan program aplikasi Android dan pengembangan Aplikasi Kota B. Beberapa rekomendasi studi meliputi:

1. Perlu diperhatikan terkait operasional penggunaan program aplikasi Android dan pengembangan Aplikasi yaitu aspek keamanan dan pertanggungjawaban data dari perangkat lunak ini. Pihak yang berwenang harus memperhatikan beberapa faktor dan pertimbangan sebelum memberikan izin penggunaan perangkat lunak ini kepada pengguna (user).

2. Adanya SDM yang mempunyai keahlian dibidang IT dibutuhkan untuk mendukung penggunaan sistem dan teknologi informasi terutama di daerah sangat diperlukan. Oleh karena itu sebaiknya mulai dipikirkan mekanisme untuk menyediakan SDM di bidang IT untuk membantu penggunaan aplikasi android dan Aplikasi ini

\section{Daftar Pustaka}

[1] A.S, Rosa, dan Shalahuddin, M. 2013. Rekayasa Perangkat Lunak Terstruktur dan Berorientasi Objek. Bandung: Informatika Bandung.

[2] Arief (2011) Pemrograman Web Dinamis Menggunakan PHP Dan MySQL. Yogyakarta: Andi.

[3] Denny Carter, Irma Agtrisari (2003) Desain dan Aplikasi SIG. Jakarta : PT Elex Komputindo.

[4] Peraturan Pemerintah Nomor 15 Tahun 2010 tentang Penyelenggaraan Penataan Ruang.

[5] Peraturan Daerah Kota Bogor Nomor 6 Tahun 2014 tentang Rencana Pembangunan Jangka Menengah Daerah Kota Bogor 2015-2019

[6] Peraturan Walikota Bogor Nomor 28 tahun 2011 tentang Izin Pemanfaatan Ruang.

[7] Undang-Undang Nomor 26 Tahun 2007 tentang Penataan Ruang 